\title{
Exploring Sustainable Urban Transformation Concepts for Economic Development
}

\author{
ELINA MIKELSONE ${ }^{1}$, DZINTRA ATSTAJA*2, VIKTOR KOVAL ${ }^{3}$, INGA UVAROVA ${ }^{4}$, \\ INESE MAVLUTOVA ${ }^{5}$, JEKATERINA KUZMINA ${ }^{6}$ \\ ${ }^{1}$ School of Business and Finance; Idea Innovation Institute Ltd. LATVIA. \\ 2,5,6 School of Business and Finance. LATVIA. E-mail: dzintra.atstaja@ba.Iv \\ ${ }^{3}$ National Academy of Sciences of Ukraine. LATVIA. \\ ${ }^{4}$ School of Business and Finance; Artsmart Ltd. LATVIA.
}

\begin{abstract}
Nowadays cities face numerous challenges amplified to build necessary urban municipal and community capacity to ensure sustainability transformation to respond to the local and global challenges of climate change, inequality, and access to resources. This research combines the study fields of sustainability, economic development, governance of sustainability transformation, providing the multidisciplinary approach as a systemic-oriented view encompassing the social, technological and ecological aspects of urban transformation. The purpose of the paper is to explore how the concept of urban transformation could be operationalized for research of economic development under the economic strain assuming the emergency of Covid-19 grand challenge. The research methods used are a systematic literature review and the content analysis. The paper provides a detailed characterization of the urban transformation exploring this concept from the structure and system perspectives for the economic exit from the crisis.
\end{abstract}

Key words: urban, sustainable urban transformation, economic development, Covid-19, critical literature review

JEL Classification: R11, P25, Q56 


\section{Introduction.}

This paper explores the emerging phenomena of sustainable urban transformation. The European Commission and other governmental organizations prove the importance of this topic by streamlining and amplifying smart and sustainable transition within the European Green Deal Strategy [1] as well the legal and planning documents related to the EU structural funds planned for forthcoming seven years beyond 2020 .

The significance of the sustainable urban transition is highlighted with the Urban Agenda for the EU [2] defining the strategic direction for policy makers, urban development planners and other practitioners related to the development of the urban areas. The Urban Agenda strives to facilitate the adoption of integrated and coordinated approaches that provide greater impact on the development of urban areas safe, clean, resilient, and sustainable, with the main emphasis upon smart, inclusive, urban-friendly, effective and efficient solutions.

In addition, the New Urban Agenda of United Nations encouraged the paradigm transformation promoting the development of a better and more sustainable future of cities and urban spaces. The New Urban Agenda defends the need to leverage urbanisation for structural transformation, sustainable economic growth, value-added activities and resource efficiency [3].

The research is based on the literature review and provides understanding on how to conceptualize urban transformation. The urban transformation explored through:

- basic information about research field, research level, methods;

- research focus: systems and structures;

- main assumptions: involvement, institutional context, living/policy laboratories, resilience, technologies, influencing factors;

- Covid-19 impact.

For the exploring urban transformation concepts for economic development basic literature review was used, based on a systematic and analytical review of the literature in the SCOPUS database, which summarised the main assumptions to be considered when developing and implementing this approach.

The authors provide the general overview of the urban transformation concept and then explore a deeper context of the urban transformation from the perspectives of economic development assuming the influence caused by the crises or grand challenges, like the Covid-19 pandemic.

The research analyses the theories, concepts and considerations of scholars forming the theoretical foundations for the phenomena of the urban transformation. The paper determines main assumptions of the urban transformation regarding economic development and contributes with alter knowledge situating this research area in the context of crises caused by the Covid-19. The research results embrace a different perspective and convince the necessity of combining several disciplines from the system and structure viewpoint.

The research the identification of additional in order to facilitate the understanding of the urban transformation in the circumstances of the economic change derived by grand pandemic crises.

This article is organised in three consecutive parts. The next section describes the methodological framework and research methods. The third section provides the research results of the systematic literature review. The 4th section includes the discussion about the pre-assumptions of the analysed field identifying the main implication areas. The main conclusions are synthesized in the last part of this research paper.

\section{Methodological Framework.}

The critical literature review was applied as the general data gathering method. The data were later analysed using the content analysis. 
Limitations for the selection of literature sources: (1) Social Sciences; (2) Urban Studies; (3) 20 journals with highest ratings (Cite Score). Within this study the main seeding sources for the critical literature analyses have their origin and publication on the SCOPUS in the period from 2016 till 1st quarter 2021, but in the content analysis recited also sources from those articles using purposive sampling method. In the first collection of the literature sources in total 230 journals of SCOPUS data base under Social Sciences and Urbans Studies were identified for the analyses. Then TOP 50 journals according to the Cite Score citation were filtered for the literature review.

Authors have summarised the main assumptions and purposes for literature review from relevant previous research $[4,5,6,7,8]$ :

1. Delimiting the research problem;

2. Seeking new lines of inquiry;

3. Avoiding fruitless approaches;

4. Identifying recommendations for further research (exploring research gaps);

5. Exploring important variables relevant to the topic;

6. Identifying the main methods, literature, theories that have been used;

7. Give an overview about the research field, main findings in the area.

Data collection was conducted in 4 stages: (1) research of scientific database SCOPUS to explore literature where term "urban transformation" is mentioned, (2) selection of literature directly about these terms and exclusion of duplicates; (3) limitations for literature studies in the search engine: (1) Social Sciences; (2) Urban Studies; (3) 20 journals with highest ratings (Cite Score) appliance of selected literature. Originally included scientific from 2016- 2021 1st quarter, but in content analysis recited also sources from those articles. From 230 SCOPUS journals under Social Sciences and Urbans Studies were included only articles from TOP 50 journals according to the Cite Score. All the sources that passed the stage 3 were analysed with content analysis. Content analysis was conducted in 3 steps: (1) preparation - gathering literature source analysis protocols; (2) organization - initial coding was conducted nonlinearly: there were predefined, and data driven; (3) report development - described categories. The category network is provided in Figure 1.

As Figure 1 shows, the main research trends in urban transformation are sustainable growth, crises and security, resilience, technologies, societal involvement, living laboratories, social sustainability, energy transition.

\section{Results.}

\subsection{The state of knowledge and theoretical grounding of the urban transformation.}

Using critical literature review as the general data gathering method, the data were analysed through content analysis. Basic literature review based on the systematic and analytical literature review in SCOPUS database revealed the main assumptions that should be taken in account while developing this approach. Subsequently restrictions on literature analysis were imposed with following criteria: (1) Social sciences, (2) Urban environment research, (3) 20 journals with the highest rating (Cite Score). Initially, scientific data from 2016- 2021 1st quarter were included in the analysis, but the sources of these articles were also mentioned in the content analysis. 
Figure 1. Research category network

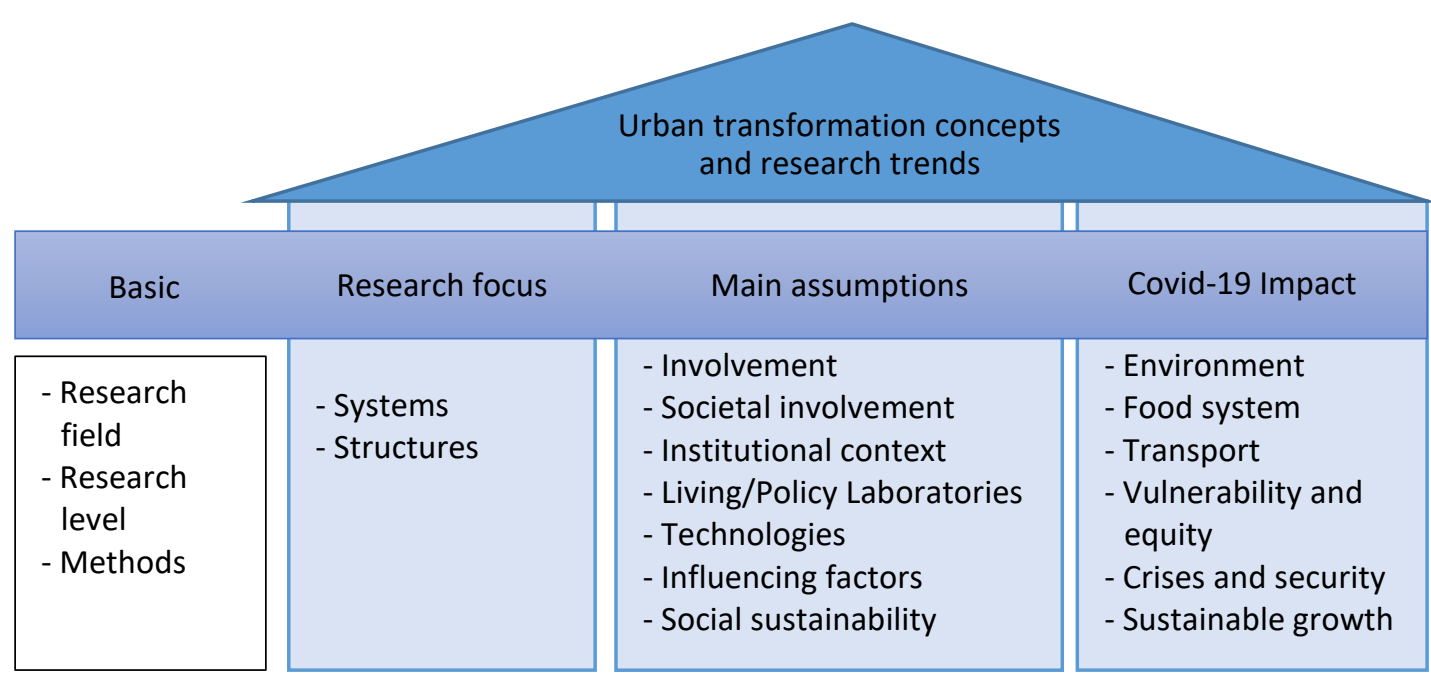

Source: compiled by the authors

Authors used Google Ngram Viewer's corpus to analyse the frequency and the amount of the papers published in relation to the research topic. The interest of academics on the topic "urban transformation" has been growing slowly sing 1970s with more intense increase in the last two decades (Figure 2).

Figure 2. Number of articles in the search of keywords "urban transformation"

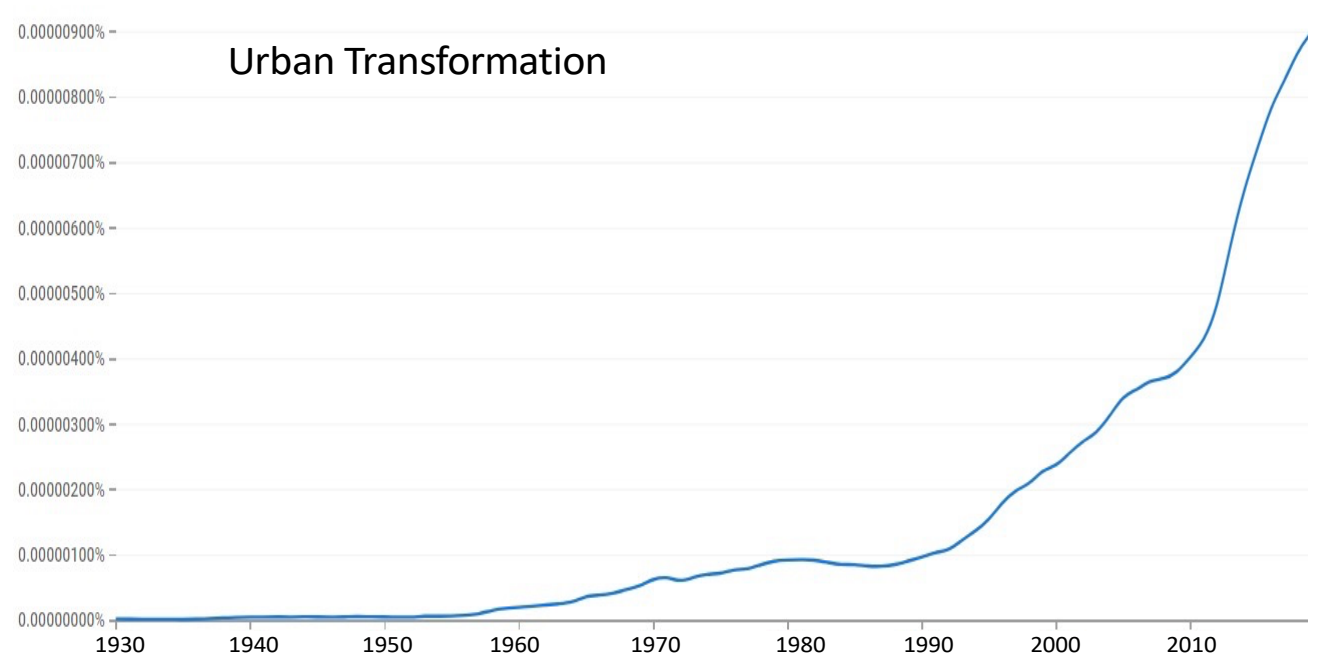

Source: compiled by the authors using Google Ngram Viewer

The data collected in Figures 3 demonstrate that with scientific debate issues related to the sustainable urban transformation have been sharply growing over the last decade. For the analyses of the articles published following keywords were used "urban transformation" and "sustainable urban transformation". The X axis shows the year in which works from the corpus were published, and the $Y$ axis shows the frequency with which the Ngrams appear throughout the corpus.

The systematic critical literature review reveals following presumptions. The authors believe that the urban transformation could be explored from several aspects. 
Figure 3. Number of articles in the search of keywords "sustainable urban transformation"

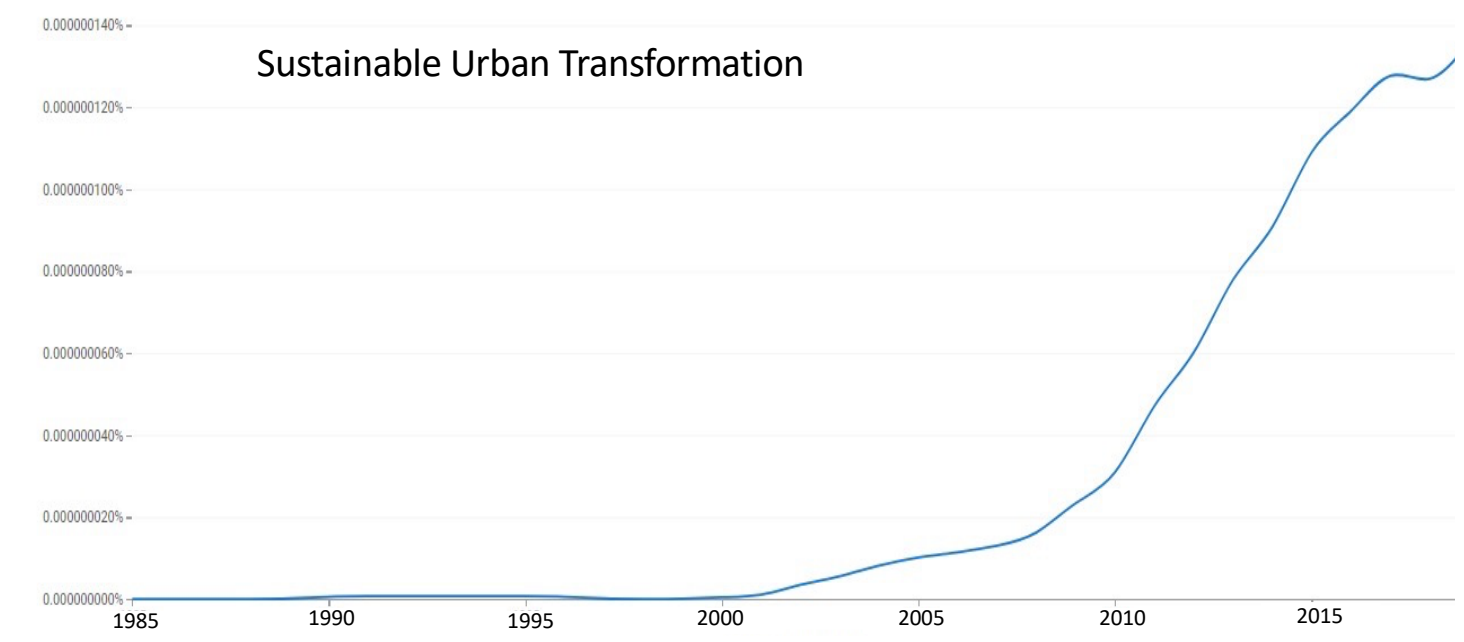

Source: compiled by the authors using Google Ngram Viewer.

Table 1. More Frequently Applied Methods

Subcategory Examples of objectives

\begin{tabular}{|c|c|c|c|}
\hline \multirow{4}{*}{$\begin{array}{c}\text { Data } \\
\text { Collection }\end{array}$} & & & \multirow{2}{*}{ Williams \& Needham [18] } \\
\hline & $\begin{array}{l}\text { Interviews } \\
\text { Focus group } \\
\text { Questionnaire }\end{array}$ & $\begin{array}{l}\text { To research views about possible } \\
\text { improvements (with the aim to introduce } \\
\text { new systems). To verify information } \\
\text { interpretation. To evaluate a concrete } \\
\text { system, its effectiveness and application, } \\
\text { influencing factors. To supplement other } \\
\text { collected data. To develop and to test new } \\
\text { systems. To collect data to research } \\
\text { correlations. }\end{array}$ & \\
\hline & $\begin{array}{l}\text { Case studies } \\
\text { Observation }\end{array}$ & $\begin{array}{l}\text { To research dynamics in different systems. } \\
\text { To create new systems. To collect specific } \\
\text { requirements for systems. To collect good } \\
\text { practices. To research different } \\
\text { mechanisms and factors. }\end{array}$ & $\begin{array}{l}\text { Shamsuzzoha et al. [17]; } \\
\text { Gun et al. [15]; Davies } \\
\text { \&Brooks [19]; Turkkan } \\
\text { [16]; Garcia-Ayllon [20] }\end{array}$ \\
\hline & $\begin{array}{l}\text { Databases, } \\
\text { vector data; } \\
\text { secondary } \\
\text { data }\end{array}$ & $\begin{array}{l}\text { To research different mechanisms and } \\
\text { factors. }\end{array}$ & $\begin{array}{l}\text { Yang et al. [5]; Garcia- } \\
\text { Ayllon [20] }\end{array}$ \\
\hline \multirow[t]{4}{*}{$\begin{array}{l}\text { Data } \\
\text { Handling } \\
\text { and Data } \\
\text { Analysis }\end{array}$} & $\begin{array}{l}\text { Participant } \\
\text { analysis }\end{array}$ & $\begin{array}{l}\text { To create a representative description of } \\
\text { system users, application dynamics. }\end{array}$ & $\begin{array}{l}\text { Shamsuzzoha et al. [17]; } \\
\text { Gun et al. [15]; Morrison } \\
\text { \& Van Den Nouwelant } \\
\text { [21] }\end{array}$ \\
\hline & Statistical & $\begin{array}{l}\text { To research dynamics, effectiveness, } \\
\text { application. To evaluate correlations. }\end{array}$ & $\begin{array}{l}\text { Yang et al. [5]; Garcia- } \\
\text { Ayllon [20] }\end{array}$ \\
\hline & $\begin{array}{l}\text { Analysis of } \\
\text { systems }\end{array}$ & $\begin{array}{l}\text { To analyse empirical new methods or } \\
\text { systems. To compare systems. }\end{array}$ & $\begin{array}{l}\text { Shamsuzzoha et al. [17]; } \\
\text { Gun et al. [15] }\end{array}$ \\
\hline & $\begin{array}{l}\text { Simulations/ } \\
\text { experiments }\end{array}$ & $\begin{array}{l}\text { To evaluate a concrete system, its } \\
\text { effectiveness and application, influencing } \\
\text { factors. }\end{array}$ & Bulkeley et. al. [22] \\
\hline Basic & $\begin{array}{l}\text { Literature } \\
\text { reviews }\end{array}$ & $\begin{array}{l}\text { Research literature. } \\
\text { To create a new system, classification, } \\
\text { model }\end{array}$ & $\begin{array}{ll}\text { Morrison \& Van } & \text { Den } \\
\text { Nouwelant [21]; } & \text { van } \\
\text { Oostrum [23] } & \end{array}$ \\
\hline
\end{tabular}


Based on Zagrofos et al. [9], first, transformation involve a more effective integrated and coordinated approach to EU policies and legislation with a potential impact on urban non-linear changes at an enlarged scale of systems, places, and locations; second, transformation address dealing with failures of economic development, including increasing greenhouse gas emissions; third, fundamental changes within a system that itself produces climate change vulnerability both elsewhere and within its contours [10]; fourth, confront main causes of climate change by engaging with the politics of managing risk [11] and reshapes existing local politics to overcome barriers based on unstimulating institutional norms, uneven power structures $[12,13,14]$.

According to the authors considering these elements, to understand the urban transformation there is a need for a frame that explicitly includes outcome and process. Subsequently in the next chapters will be researched potential elements to include in such a frame.

The urban transformation could be studied from a number of research fields: Urban Studies, Geography, Planning and Development, General Environmental Science, Ecological Modelling and Economics. In addition, this issue can be investigated from various research levels. By authors, the dominating research level is the city level and group level research. Nevertheless, some country and regional research are also important. For example, Gun et al. [15] created a participatory design model for Istanbul, but Turkkan [16] researched food supply chains in Istanbul.

Very common experience is to compare different city experiences in different regions, like in Shamsuzzoha et al. [17] where they create a comparison of participatory strategies for a smart city for sustainable environment from Helsinki, Singapore and London. Less common is concentration on the individual level aspects.

As shown in the Table 1, the authors identified that the most frequent applied data analysis methods are content analysis and statistical methods, and the most frequent applied data selection methods are case studies and data base/document analysis.

\subsection{The perspectives of systems and structures}

The authors argue that the structure related literature sources focus on the rules and resources that systems employ having focus on the design and the process, but the system related literature sources pay attention to patterns of relations focusing on the social capital, creativity and other factors. The Figure 4 demonstrates systemic and structural perspectives.

The analysis proves that both structure and system elements are explored in the literature, that means that also researching the urban transformation it is very important to research both elements, especially how they influence each other through the structuration process. Interrelations of these elements regarding the urban transformation are shown in Table 2.

Table 2 indicates the main focuses of the urban transformation research are the literature review, observations, case studies, experimental projects, creation of new models and the participant analysis. Practitioners and policy makers are keen to use various forms of the evaluation exploring the aspects of effectiveness, impact, efficiency and sustainability of various incentives, tools and approaches applied in the urban transformation. 
Figure 4. Systems and Structures

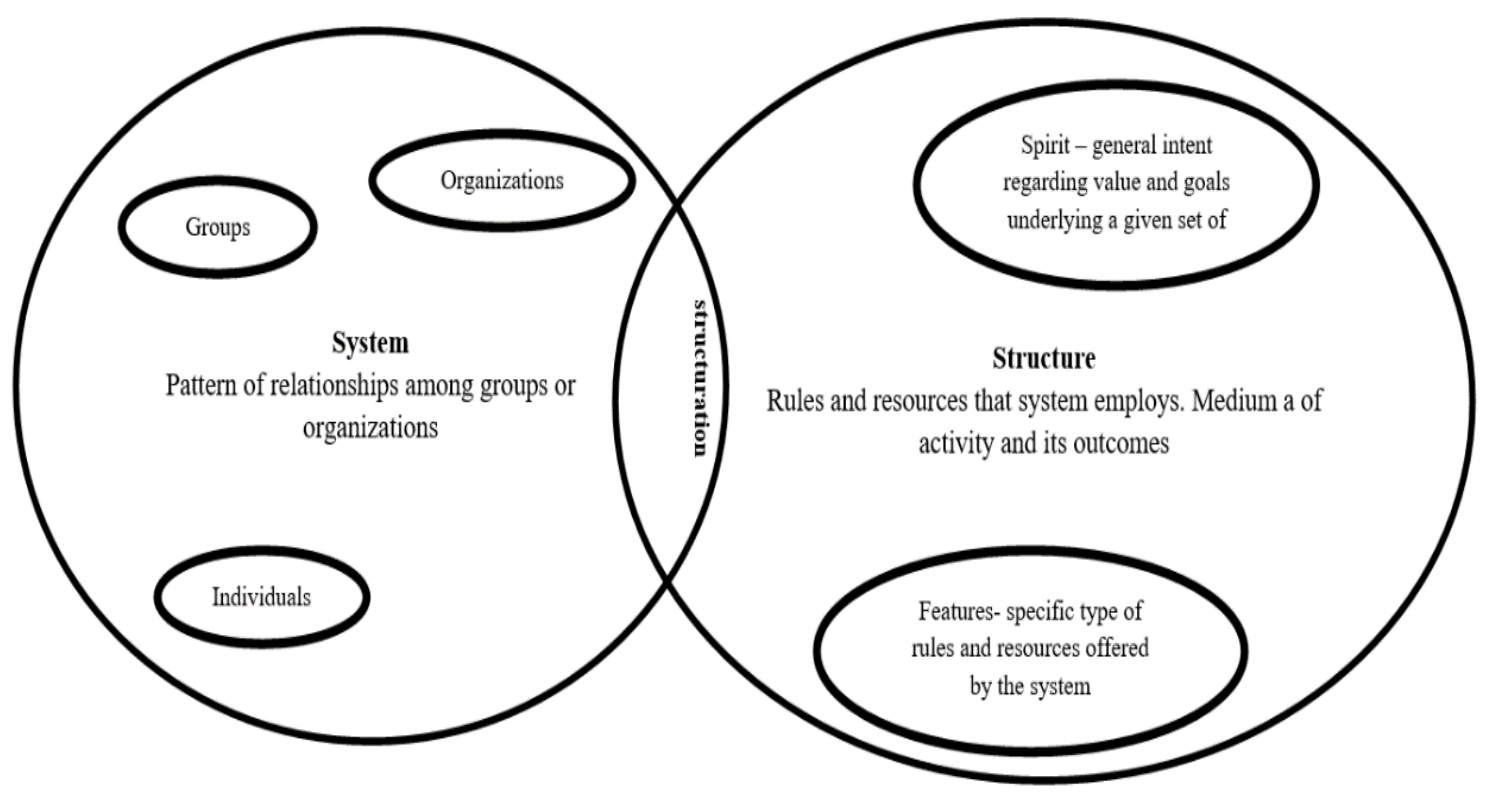

Source: [24]

Table 2. Research Focus: Systems and Structures

Approach

Focuses, for example

Most Frequent Applied

Methods

\section{Systems}

Social capital

Evaluation of

For example, Shamsuzzoha et al. [17];

effectiveness

Gun et al. [15]; Morrison \& Van Den

Nouwelant [21]; Williams \&

Good practises

Needham [18]

Participant analysis

Literature review

Simulation

Interviews

Questionnaire

Observation

Case studies

Statistics

\section{Structures}

For example, Shamsuzzoha et al. [17]; Gun et al. [15]; Davies \& Brooks [19]; Yang et al. [5]; van Oostrum [23]; Bulkeley et. al. [22]

Structure,
design, features,
process etc.
Experimental project
Creation of new models
Structure evaluations
Good practises

Focus group/Interviews Literature review

Simulation

Questionnaire

Observation

Vector Data

Case studies

Statistics

Factor analysis

\section{Discussion.}

\subsection{Main assumptions.}

The authors of this study adapted the method of the systematic literature review and the technique of the content analysis. The synthesis of the research results reveals several aspects important for urban transformation, such as involvement of various actors, societal involvement, institutional context, living laboratories, resilience, technologies, influencing factors including COVID-19.

Involvement of Various Actors in Urban Transformation. A lot of urban studies proves that various actors responsible for converting a traditional to a smart city can contribute to environmental 
sustainability [25]. Shamsuzzoha with co-authors [17] conclude that the current research on smart city does not fully address the complex nature, conflicts and interdependencies. Analysed research prove that smart initiatives involve a lot of partners and use technologies and data, citizen involvement and the aims to create more sustainable socially, economically and environmental balanced cities [26, 27].

The societal involvement in the urban transformation processes is recently an increasing issue. While many authors are keen to explore the technological aspects of the urban transformation, the human factors cannot be neglected $[28,29]$. Odendaal [30] argues that the sole focus on the technological side does not allow a broader context in the "contemporary urbanity" and should assume the societal dimension, local dynamics and specifics of particular neighbourhoods of urban settlements.

The European Commission, policy makers, and other international organisations have already acknowledged the importance of the involvement of the society or local communities in the development, improvement and provision of public services, public infrastructure and other facilities. However, public administrations and local governments are currently searching for the most appropriate approaches and tools for activation and involvement of individuals.

Public involvement is essential to create an urban environment that is functionally comfortable, modern, accessible, safe and enjoyable for its residents and visitors assuming the needs of individuals. Previous research defines the importance of the application of the user experience approach in relation to the development and transformation of public services, infrastructure and facilities addressing sustainability issues [31, 32].

These issues have been discussed among the researchers already for several decades, but currently have got increased attention due to the introduction of the smart solutions in the urban transformation process, for instance, the smart public lighting systems [33, 34]. The co-creation is another term that is widely used and known in the business environment, but now gradually is being used in the relation to the public services and urban transformation processes [35]. Involvement of residents helps to get a wider range of ideas about the necessary multifunctional solutions for the needs of city residents and guests. This in turn requires much greater engagement from the community and representatives of local communities to participate in and self-manage various urban transformation processes.

Urban Transformation in Institutional Context. Smart governance in institutional context is also the sharply discussed topic in the research. The existing research explores multi-layered institutional influencing arguing that institutions on multiple scales interact and alter each other's impact on the smart governance. These interactive dynamics logically determine the institutional factors shaping smart governance in diverse city contexts [36,37]. Smart governance is citizen centric [38] and citizens are vital drivers of urban transformation actively engaging in all processes [39]. This opinion has close synergies with the assumption of the societal involvement described above.

These approaches have stimulated many city governments to launch technology driven collaboration projects $[26 ; 40]$. Previous research highlights that now urban transformation projects relatively less focus on public participations and dialogue-oriented smart city solutions [41]. Morrison \& Van Den Nouwelant [21] examine the governance arrangements driving forward the growth vision and drawing on the collaborative governance theory to critically examine the workings of the partnership arrangement.

Living/Policy Laboratories. There is a growing interest in using cities as 'living laboratories', with the aim to develop and test responses to sustainability challenges present in the urbanism [42]. There is a growing tendency for cities to become like a site for learning and experimentation in the local environment $[22,43,44]$. The approach to pilot smart city innovations has been promoted through various European support instruments, like, Horizon 2020 with, for instance, Era-Net Cofund calls for proposals [45]. 
Urban Transformation and Resilience. Studies of the resilience of smart cities can provide new insights about the sustainable urban development by highlighting the importance for improving urban carrying capacity, disaster resistance and development capacity [46].

Urban Transformation and Technologies. In this connection, Gun et al. [15] map urban transformation processes in Istanbul by tracing how these practices are implemented by making use of contextualised ICT-based participation tools and techniques.

Influencing factors. Both internal and external factors are described in scientific literature. For example, Yang et al. [47] conducted qualitative analysis that proved spatial transformations that were influenced by external development conditions and internal resources.

Social sustainability. While the sustainable development is associated with the social, economic and envirnmental transition processes, the social sustainability on the context of the urbanity is a concept requiring more detailed interpretation. In general terms, the social sustainability can be associated with the social dimension within the socio-economic growth of particular cities or urban spaces. Dempsy with co-authors [48] identifies detailed elements related to the social sustainability such as the social capital, empowerment of local comunities and active participation of citizens, social equity and justice, socially beneficial public infrastructure and accessibility of services. The social sustainability promotes the development of the urban space as an attractive environment for people living, visiting, studieing and working there assuming various social non-physical and physical factors important for the human needs to live in a safe, resiliant, green and pleasant areas [48, 49,50]. In addition, the previous research introduces the "socially aware planning" advocating the imporatnce of cooperation networks and "pro-community behaviours" of various stakeholders motivated to act and support each other in order to improve the wellbeing and the quality of life of local communities, safe and secure living in neighbourhoods [51].

\subsection{Economic development and Covid-19 impact.}

There is no doubt that the outbreak of Covid-19 pandemics has impacted the choice of research questions. Therefore, the authors of the current paper cannot ignore this issue and provide a summary of the findings regarding this aspect of the research. It is worth considering that the issue "Sustainable Urban Transformation and Covid-19" is still under development and the number of the published research papers is limited. Nevertheless, researchers have started to highlight the importance to look for insights from early Covid-19 responses about promoting sustainable [52]. It is important to make people aware that the pandemic has disruptive impacts on social, economic systems and also influenced environmental aspects.

Covid-19 Impact and Environmental Problems. The sustainable urban transformation and the necessity for changes concerning the negative environmental impact have been discussed earlier. The researchers continued the development of the topic in the context of Covid-19 pandemics - evaluating the impacts of lockdown over the quality of life in the cities measured through the combination of air quality, meteorological parameters, and mobility data [53]. The most relevant evidence is the proven complexity of the negative environmental impact issue and the necessity for steady decarbonization efforts across all emission sectors to achieve the sustainability goal. Similar findings are provided by other researchers [54, 55].

Covid-19 Impact and Food system/ Urban Agriculture. The food resilience in cities and food selfsufficiency through urban agriculture are relevant discussion elements in times of crisis, while Covid19 pandemics are not an exception. The latest global challenge has highlighted the existing problems and necessities to solve them [56]. The problematic issues include lacking attention to social and ecological vulnerabilities and risk-related inequalities; the indifference to the increased negative environmental impact, as well as missing reflection on recycling potentials in cities $[57,58,59]$.

Covid-19 Impact and Transportation. The requirement of social distancing was a trigger to reconsider the usage of e-bikes as city transportation means - one can note the increasing role of the e-bike as a reliable transport mode and the growing potential for e-bikes as substitutes for public 
transport in the post-pandemic world [60]. Other researchers also underlined the trend of sustainable mobility supported by the Covid-19 outbreak [61].

Covid-19 Impact and Vulnerability. The Covid-19 has raised the issue of accessibility of services and goods, especially for vulnerable groups. The mutuality, reliability and ability of vulnerable groups to access and use the resources. In this context recent practices showed high pro-communitity behaviour in sharing resources and providing multiple benefits to improve the social equity to inhabitants. The sharing has got a particular interest during the Covid-19 pandemic in relation to the vulnerable groups, even providing emergency solutions for improving the safety and security of vulnerable individuals [62].

Covid-19 Impact and Security. The analyses show the importance of the range of evaluative criteria and indicators of secure, safe, sustainable living environment, affordable energy provision, socioeconomic, cultural and political dimensions, and individual well-being and health. The World Economic Forum [63] has announced resent global risks highlighting the extreme need for global collaboration to treat the Covid-19 grand challenge and ensure the economic recovery, but also, suggesting not to loose attention from other significant risks related to the safety and security such as the weapons of mass destruction, cyber security and pottential attacks towards the IT infrastructure breakdown, geopolitical risks, interstate relations fracture and conflicts. These risks may arise from global implications, but may cause cathastrophic crises that directly and locally endangering the security of cities and their inhabitants [58].

Covid-19 Impact and Sustainable Growth. While governments and communities are actively communicating the emergency and disaster plans to secure health of humans, the sustainability issues have been neglected, there are threats of falling back at least 10 years ago in terms of the progress on sustainable growth [63]. With the second wave of Covid-19 lockdown more attention is paid to the necessity of maintaining the urban nature, developing "urban greenspaces" [58]. In the moment when the society acquire the beliefe to combat the Covid-19 pandemic disease with newly invented vacines, Covid-19 pandemic is stimulating the increase of the plastic waste in such contributing to the to worldwide plastic pollution due to increased needs of packaging for "deliveries to home", disposable tableware, face-masks and other means [58,64]. From other hand Covid-19 pandemic has some positive influence on the sustainable consumtion, especially in urban areas motivating humans for local sustainable tourism activities, more considered purchases of products reducing useless and spontanious purchases, and in general stimulating the acknowledgement of the pro-environmental behaviours [65].

Substantially that urban transformation is researched also as indicators of economic change [6668], therefore, it provides guidance for future research directions to study urban transformation as an indicator of economic changes during Covid-19.

\section{Conclusions.}

Based on the systematic and analytical scientific literature review the authors came to the following conclusions:

1. Urban transformation could be explored from different perspectives: involvement in non-linear changes at an enlarged scale of systems, places, and locations; dealing with failures of economic development; climate change; power structures.

2. Changes in urban practices, sector organization and infrastructure are driven by complex systems, the urban transition amounts to a 'deep' transition, a transversal change process unfolding across subsystems, organizational fields and policy domains

3. The authors identified that the most frequent applied data analysis methods on urban transformation are content analysis and statistical methods and the most frequent applied data selection methods are case studies and data base/document analysis. 
4. Several aspects important for urban transformation, such as Involvement of Various Actors, Institutional Context, Living Laboratories, Resilience, Technologies, Influencing Factors were identified in frames of study.

5. Social Sciences and Humanities insights are essential requisites for the articulation of qualitative nuances and of societal impacts, which has implicit relation ship with the economic development and growth processes.

6. Urban transformation could be considered as indicators of economic change and provides guidance for future research directions to study urban transformation as an indicator of economic changes during COVID-19, such as environmental problems and potential solutions, the role of urban agriculture, trends in transportation means.

\section{Acknowledgements.}

The paper was supported by the BA School of Business and Finance internal grant BA2020/1 project "Modern teaching methods to promote the development of sustainable entrepreneurial thinking" and the project of Latvian Council of Science No. Izp-2020/2-0317 "The Impact of COVID-19 on Sustainable Consumption Behaviours and Circular Economy".

\section{References}

1. European Commision (EC). (2019). Communication from the Commission to the European Parliament, the Council, the European Economic and Social Committee and the Committee of the Regions. The European Green Deal. Brussels, 11.12.2019.

2. EC. (2017). Report from the Commission to the Council on the Urban Agenda for the EU. Brussel, COM (2017) 657 final.

3. United Nations (UN). (2017). The New Urban Agenda. ISBN: 978-92-1-132731-1.

4. Gall, M. D., Borg, W. R., \& Gall, J. P. (1996). Education research: An introduction (6th ed.), NY: Longman.

5. Hart, C. (1999). Doing a Literature Review: Releasing the Social Science Research Imagination. London: Sage.

6. Boote, D. N. \& Beile, P. (2005). Scholars before researchers: On the centrality of the dissertation literature review in research preparation. Educational Researcher, 34(6), 3-15. https://doi.org/10.3102/0013189X034006003

7. Bolderston, A. (2008). Writing an Effective Literature Review. Journal of Medical Imaging and Radiation Sciences, 39(2), 86-92. https://doi.org/10.1016/j.jmir.2008.04.009

8. Boell, S., K. \& Cecez-Kecmanovic, D. (2010). Literature reviews and the hermeneutic circle. Australian Academic and Research Libraries, 41 (2), 129-144. https://doi.org/10.1080/00048623.2010.10721450

9. Zografos, C, Klause, K.A. Connolly, J.J.T. \& Anguelovski, I. (2020). The everyday politics of urban transformational adaptation: Struggles for authority and the Barcelona superblock project, Cities, 99, 102613, ISSN 0264-2751, https://doi.org/10.1016/j.cities.2020.102613

10.Du, M., \& Zhang, X. (2020). Urban greening: A new paradox of economic or social sustainability?. Land Use Policy, 92, 104487. https://doi.org/10.1016/j.landusepol.2020.104487

11.Connolly, J. J. T. (2018). From systems thinking to systemic action: Social vulnerability and the institutional challenge of urban resilience. City \& Community, 17(1), 8-11. https://doi.org/10.1111/cico.12282

12.Araos, M., Berrang-Ford, L., Ford, J. D., Austin, S. E., Biesbroek, R., \& Lesnikowski, A. (2016). Climate change adaptation planning in large cities: A systematic global assessment. Environmental Science \& Policy, 66 (December 2016), 375-382. https://doi.org/10.1016/j.envsci.2016.06.009 
13.Di Giulio, G. M., Bedran-Martins, A. M. B., da Penha Vasconcellos, M., Ribeiro, W. C., \& Lemos, M. C. (2018). Mainstreaming climate adaptation in the megacity of São Paulo, Brazil. Cities, 72, 237244. https://doi.org/10.1016/j.cities.2017.09.001

14.Torabi, E., Dedekorkut-Howes, A., \& Howes, M. (2018). Adapting or maladapting: Building resilience to climate-related disasters in coastal cities. Cities, 72, 295-309. https://doi.org/10.1016/j.cities.2017.09.008

15.Gun, A., Pak, B. \& Demir, Y. (2021). Responding to the urban transformation challenges in Turkey: a participatory design model for Istanbul, International Journal of Urban Sustainable Development, 13:1, 32-55, DOI: 10.1080/19463138.2020.1740707

16.Turkkan, C. (2020). Feeding the global city: urban transformation and urban food supply chain in 21st-century Istanbul, Journal of Urbanism: International Research on Placemaking and Urban Sustainability, 13:1, 13-37, DOI: 10.1080/17549175.2018.1515785

17.Shamsuzzoha, A., Nieminen, J., Piya, S. \& Rutledge, K. (2021). Smart city for sustainable environment: A comparison of participatory strategies from Helsinki, Singapore and London, Cities, 114, ISSN 0264-2751, https://doi.org/10.1016/j.cities.2021.103194

18.Williams, T.L. \& Needham, C.R. (2016). Transformation of a City: Gentrification's Influence on the Small Business Owners of Harlem, New York. SAGE Open. doi:10.1177/2158244016673631

19.Davies, A. \& Brooks, A. (2019). Interpellation and Urban transformation: Lisbon's sardine subjects, Social \& Cultural Geography, DOI: 10.1080/14649365.2019.1647347

20.Garcia-Ayllona, S. (2018). Urban transformations as indicators of economic change in postcommunist Eastern Europe: Territorial diagnosis through five case studies, Habitat International, 71, 29-37, https://doi.org/10.1016/j.habitatint.2017.11.004

21.Morrison, N. \& Van Den Nouwelant, R. (2020). Western Sydney's urban transformation: examining the governance arrangements driving forward the growth vision, Australian Planner, 56:2, 73-82, DOI: $10.1080 / 07293682.2020 .1742172$

22.Bulkeley, H, Marvin, S, Voytenko Palgan, Y, McCormick, K, Breitfuss-Loidl, M, Mai, L, von Wirth, T, Frantzeskaki, N (2019) Urban living laboratories: conducting the experimental city. European Urban and Regional Studies 26(4): 317-335. https://doi.org/10.1177/0969776418787222

23.Van Oostrum, M. (2020). Informal laneway encroachment: Reassessing public/private interface transformation in urban villages, Habitat International, 104, 102259, https://doi.org/10.1016/j.habitatint.2020.102259

24.Mikelsone, E. (2020). The Summary of Dissertation Thesis "Impact of Idea Management System Application Type on Idea Management Results in Enterprises". BA School of Business and Finance: Riga.

25.Chu, E., Brown, A., Michael, K., Du, J., Lwasa, S., \& Mahendra, A. (2019). Unlocking the Potential for Transformative Climate Adaptation in Cities. Background Paper prepared for the Global Commission on Adaptation, Washington DC and Rotterdam

26.Albino, V., Berardi, U., \& Dangelico, R. M. (2015). Smart cities: Definitions, dimensions, performance, and initiatives. Journal of Urban Technology, 22(1), 1-19. https://doi.org/10.1080/10630732.2014.942092

27.Tomor, Z., Meijer, A., Michels, A., \& Geertman, S. (2019). Smart governance for sustainable cities: Findings from a systematic literature review. Journal of Urban Technology, 26(4), 3-27. https://doi.org/10.1080/10630732.2019.1651178

28.Charnock, G., March, H., \& Ribera-Fumaz, R. (2021). From smart to rebel city? Worlding, provincialising and the Barcelona Model. Urban Studies, 58(3), 581-600. https://doi.org/10.1177/0042098019872119 
29.Spicer, Z., Goodman, N., \& Olmstead, N. (2021). The frontier of digital opportunity: Smart city implementation in small, rural and remote communities in Canada. Urban Studies, 58(3), 535-558. https://doi.org/10.1177/0042098019863666

30.Odendaal, N. (2020). Everyday urbanisms and the importance of place: Exploring the elements of the emancipatory smart city. Urban Studies, 58(3), 639-654. https://doi.org/10.1177/0042098020970970

31.Dimante, D., \& Atstaja, D. (2010). The economies of the Baltic Sea Region in relation to green economics, with particular focus on Latvia: environmental sustainability and well-being. International Journal of Green Economics, 4(3), 292-305 https://doi.org/10.1504/IJGE.2010.037529

32. Hutsaliuk, O., Koval, V., Tsimoshynska, O., Koval, M., Skyba, H. (2020). Risk Management of Forming Enterprises Integration Corporate Strategy. TEM Journal, 9(4), 1514-1523. https://doi.org/10.18421/TEM94-26

33.Das, M., Das, H., \& Mackenzie, F. (1996). Satisfaction with town services: Do user experience and satisfaction count?. Service Industries Journal, 16(2), p. 191-205. https://doi.org/10.1080/02642069600000021

34.Heiskanen, O., \& Acharya, K. (2017). Envisioning the future of public lighting with citizens for upcoming technologies. The Design Journal, 20(sup1), S1782-S1793. https://doi.org/10.1080/14606925.2017.1352698

35.Poulsen, E. S., Morrison, A., Andersen, H. J., \& Jensen, O. B. (2013, August). Responsive lighting: the city becomes alive. In Proceedings of the 15th international conference on Human-computer interaction with mobile devices and services, p. 217-226. https://doi.org/10.1145/2493190.2493218

36.Tomor, Z., Przeybilovicz, E. \& Leleux, C. (2021). Smart governance in institutional context: An indepth analysis of Glasgow, Utrecht, and Curitiba, Cities, Volume 114, ISSN 0264-2751, https://doi.org/10.1016/j.cities.2021.103195

37.Krukle, Z., Ernsteins, R., \& Brizga, J. (2017). Sustainable Mobility Governance For Urban Municipalities In Latvia: Requirements And Practice Of Social-Ecological Systems Approach And Governance Instruments. International Multidisciplinary Scientific GeoConference: SGEM, 17, 923934 DOI:10.5593/sgem2017/52

38.Batagan, L. (2011). Smart cities and sustainability models. Informatica Economica, 15(3), 80-87. https://doi.org/10.1080/00048623.2010.10721450

39.Ruijer, E., Grimmelikhuijsen, S., \& Meijer, A. (2017). Open data for democracy: Developing a theoretical framework for open data use. Government Information Quarterly, 34(1), 45-52. https://doi.org/10.1016/j.giq.2017.01.001

40.van Winden, W., \& van den Buuse, D. (2017). Smart city pilot projects: Exploring the dimensions and conditions of scaling up. Journal of Urban Technology, 24(4), 51-72. https://doi.org/10.1080/10630732.2017.1348884

41.Bjorner T. (2021), The advantages of and barriers to being smart in a smart city: The perceptions of project managers within a smart city cluster project in Greater Copenhagen, Cities, Volume 114, 2021, ISSN 0264-2751, https://doi.org/10.1016/j.cities.2021.103187

42.Vallance P, Tewdwr-Jones M, Kempton L. (2020) Building collaborative platforms for urban innovation: Newcastle City Futures as a quadruple helix intermediary. European Urban and Regional Studies, 27(4):325-341. doi:10.1177/0969776420905630

43.Karvonen, A, Van Heur, B (2014) Urban laboratories: experiments in reworking cities. International Journal of Urban and Regional Research 38(2): 379-392. https://doi.org/10.1111/1468-2427.12075

44.Compagnucci, L., Spigarelli, F., Coelho, J., \& Duarte, C. (2021). Living Labs and user engagement for innovation and sustainability. Journal of Cleaner Production, 289, 125721. https://doi.org/10.1016/j.jclepro.2020.125721 
45.Urban Europe. (n.d.). Available at: https://jpi-urbaneurope.eu/calls/intro/. Observed at 29 April, 2021.

46.Zhou Q., Zhu M., Qiao Y., Zhang X., Chen J. (2021), Achieving resilience through smart cities? Evidence from China, Habitat International, Volume 111, 2021, ISSN 0197-3975, https://doi.org/10.1016/j.habitatint.2021.102348

47.Yang, R., Zhang, J., Xu, Q. \& Luo, X. (2020). Urban-rural spatial transformation process and influences from the perspective of land use: A case study of the Pearl River Delta Region, Habitat International, 104, ISSN 0197-3975, https://doi.org/10.1016/j.habitatint.2020.102234

48.Dempsey, N., Bramley, G., Power, S., \& Brown, C. (2011). The social dimension of sustainable development: Defining urban social sustainability. Sustainable development, 19(5), 289-300. https://doi.org/10.1002/sd.417

49.Du, J., Mahendra, A., Chu, E., Brown, A., Michael, K. \& Shuaib, L. (2019). Unlocking the potential for transformative climate adaptation in cities. World Resources Institute. Available at: https://wrirosscities.org/research

50.Trettin, C., Lăzăroiu, G., Grecu, I., \& Grecu, G. (2019). The social sustainability of citizen-centered urban governance networks: Sensor-based big data applications and real-time decision-making. Geopolitics, History and International Relations, 11(2), 27-33. DOI:10.22381/GHIR11220194

51.Baldwin, C., \& King, R. (2018). Social sustainability, climate resilience and community-based urban development: What about the people?. Routledge.

52.Bouman, T., Steg, L. \& Dietz, T. Insights from early COVID-19 responses about promoting sustainable action. Nat Sustain 4, 194-200 (2021). https://doi.org/10.1038/s41893-020-00626-x

53.Gualtieri, G., Brilli, L., Carotenuto, F., Vagnoli, C., Zaldei, A., \& Gioli, B. (2020). Quantifying road traffic impact on air quality in urban areas: a Covid19-induced lockdown analysis in Italy. Environmental Pollution, 267, 115682. https://doi.org/10.1016/j.envpol.2020.115682

54.Firozjaei, M. K., Fathololomi, S., Kiavarz, M., Arsanjani, J. J., Homaee, M., \& Alavipanah, S. K. (2021). Modeling the impact of the COVID-19 lockdowns on urban surface ecological status: A case study of Milan and Wuhan cities. Journal of environmental management, 286, 112236. https://doi.org/10.1016/j.jenvman.2021.112236

55.Venter, Z. S., Aunan, K., Chowdhury, S., \& Lelieveld, J. (2021). Air pollution declines during COVID19 lockdowns mitigate the global health burden. Environmental research, 192, 110403. https://doi.org/10.1016/j.envres.2020.110403

56.Uvarova, I., Atstaja, D., Grinbergs, U., Petersons, J., Gegere-Zetterstroma, A., \& Kraze, S. (2020). Transition to the circular economy and new circular business models-an in-depth study of the whey recycling. In IOP Conference Series: Earth and Environmental Science (Vol. 578, No. 1, p. 012019). IOP Publishing. doi:10.1088/1755-1315/578/1/012019

57.Langemeyer, J., Madrid-Lopez, C., Beltran, A. M., \& Mendez, G. V. (2021). Urban agriculture-A necessary pathway towards urban resilience and global sustainability?. Landscape and Urban Planning, 210, 104055. https://doi.org/10.1016/j.jenvman.2021.112236

58.Mikhno, I., Koval, V., Shvets, G., Garmatiuk, O., \& Tamošiūnienė, R. (2021). Green Economy in Sustainable Development and Improvement of Resource Efficiency. Central European Business Review, 10(1), 99-113. https://doi.org/10.18267/j.cebr.252

59.Pulighe, G., \& Lupia, F. (2020). Food first: COVID-19 outbreak and cities lockdown a booster for a wider vision on urban agriculture. Sustainability, 12(12), 5012. DOI:10.3390/su12125012

60.Kazemzadeh, K., \& Koglin, T. (2021). Electric bike (non) users' health and comfort concerns pre and peri a world pandemic (COVID-19): A qualitative study. Journal of Transport \& Health, 20, 101014. https://doi.org/10.1016/j.jth.2021.101014 
61.Schmidt, K., Sieverding, T., Wallis, H., \& Matthies, E. (2021). COVID-19-A window of opportunity for the transition toward sustainable mobility?. Transportation Research Interdisciplinary Perspectives, 100374. https://doi.org/10.1016/j.trip.2021.100374

62.Wong, S. D., Broader, J. C., \& Shaheen, S. A. (2020). Can sharing economy platforms increase social equity for vulnerable populations in disaster response and relief? A case study of the 2017 and 2018 California wildfires. Transportation research interdisciplinary perspectives, 5, 100131. https://doi.org/10.1016/j.trip.2020.100131

63.WEF. (2021). Global Risks Report 2021. 16 $6^{\text {th }}$ Edition. Insight Report. World Economic Forum.

64.Silva, A. L. P., Prata, J. C., Walker, T. R., Duarte, A. C., Ouyang, W., Barcelò, D., \& Rocha-Santos, T. (2020). Increased plastic pollution due to COVID-19 pandemic: Challenges and recommendations. Chemical Engineering Journal, 126683. https://doi.org/10.1016/j.cej.2020.126683

65.Severo, E. A., De Guimarães, J. C. F., \& Dellarmelin, M. L. (2021). Impact of the COVID-19 pandemic on environmental awareness, sustainable consumption and social responsibility: Evidence from generations in Brazil and Portugal. Journal of Cleaner Production, 286, 124947. https://doi.org/10.1016/j.jclepro.2020.124947

66.Tsimoshynska, O., Koval, M., Kryshtal, H., Filipishyna, L., Arsawan, W. E., \& Koval, V. (2021). Investing in road construction infrastructure projects under public-private partnership in the form of concession. Naukovyi Visnyk Natsionalnoho Hirnychoho Universytetu, 2, 184-192. https://doi.org/10.33271/nvngu/2021-2/184

67.Ibn-Mohammed, T., Mustapha, K. B., Godsell, J. M., Adamu, Z., Babatunde, K. A., Akintade, D. D., ... \& Koh, S. C. L. (2020). A critical review of the impacts of COVID-19 on the global economy and ecosystems and opportunities for circular economy strategies. Resources, Conservation and Recycling, 105169. https://doi.org/10.1016/j.resconrec.2020.105169

68.Lourenço, N., \& Rua, A. (2021). The Daily Economic Indicator: tracking economic activity daily during the lockdown. Economic Modelling, 105500. https://doi.org/10.1016/j.econmod.2021.105500 